DOI: https://doi.org/10.15407/techned2018.06 $: \underline{038}$

\title{
ESTIMATION OF PARAMETERS AND CHARACTERISTICS OF POWER FACTOR CORRECTOR BASED ON PULSED AND QUASI-RESONANT CONVERTERS
}

Journal

Publisher

ISSN

Issue

Pages
Tekhnichna elektrodynamika

Institute of Electrodynamics National Academy of Science of Ukraine 1607-7970 (print), 2218-1903 (online)

No 6, 2018 (November/December)

$38-41$

\section{Authors}

Yu.O. Denysov*, O.M. Gorodniy ${ }^{* *}$, V.V. Gordienko ${ }^{* * *}$, L.V. Vershniak ${ }^{* * *}$, A.V. Dymerets ${ }^{\star *}$ ***

Chernihiv National University of Technology,

Shevchenka str., 95, Chernihiv, 14035, Ukraine,

e-mail: aleksey.gorodny@gmail.com

* ORCID ID : http://orcid.org/0000-0003-2293-7964

** ORCID ID : http://orcid.org/0000-0001-5303-9564

*** ORCID ID : http://orcid.org/0000-0002-2052-9118

**** ORCID ID : http://orcid.org/0000-0001-7178-7339

***** ORCID ID : http://orcid.org/0000-0002-7617-5291

\section{Abstract}

Models of pulse converters $(P C)$ with pulse-width modulation (PWM) and zero-current-switch quasi-resonant pulse converter (QRPC-ZCS) with pulse-frequency modulation (PFM), which operate as part of a power factor corrector (PFC), are proposed. Simulation allowed to get the 
output characteristics and the dependences of the pulsation coefficients on the load variation of these converters. Also in this work comparative estimation of energy losses in PFC, transistor switches and the spectrums of consumption currents was made. References 9, figures 4, table 1.

Key words: power factor corrector, resonant circuit, quasi-resonant pulse converter, transistor switch.

Received: 05.03.2018

Accepted: 21.05 .2018

Published: 23.10 .2018

\section{References}

1. Zhuikov V.Y., Tereshchenko T.O., Yamnenko Y.S., Moroz A.V. Adjustable filters of power supplies for information security in microcontrollers. Kiev: Kafedra, 2016. 184 p. (Ukr)

2. Shydlovskyi A.K., Zharkin A.F., Pazieiev A.G., Continuous approximate model of AC/DC converters with active power factor correction. Tekhnichna Elektrodynamika. 2011. No 6. Pp. 11-17. (Ukr)

3. Denisov Y., Gordienko V., Gorodny A., Stepenko S., Yershov R., Prokhorova A., Kostyrieva O. Power losses in MOSFET switch of quasi-resonant pulse converter with series resonant circuit. $2^{\text {nd }}$ International Conference on Intelligent Energy and Power Systems (IEPS). 2016. Pp. 1-6. DOI:

doi.org/10.1109/IEPS.2016.7521869

https://

4. Denisov Y., Gorodny A., Gordienko V., Yershov R., Stepenko S., Kostyrieva O., Prokhorova A. Switch operation power losses of quasi-resonant pulse converter with parallel resonant circuit. International Scientific Conference on Electronics and Nanotechnology (ELNANO): Thirty-Fourth Annual IEEE. 2016. Pp. 327-332. 
5. Yershov R.D., Naumov D.O., Revko A.S., Tytelmaier K.O. Energy efficiency analysis in distributed electrical networks based on embedded system and combined calculation algorithm. Applied Physics, 2015 International Young Scientists Forum (YSF). 2015. Pp. 1-4. DOI: https: //doi.org/10.1109/YSF.2015.7333224

6. Gorodniy O., Gordienko V., Stepenko S., Boyko S., Sereda O. Impact of Supply Voltage Change on the Energy Performance of Boost Quasi-Resonant Converter for Radioelectronic Equipment Power Supplies. Modern Electrical and Energy Systems (MEES). 2017. Pp.

232-235.

7. S. Tomioka, S. Abe, M. Shoyama, T. Ninomiya, E. Firmansyah, A zero-current-switch quasi-resonant boost converter with transformer compensated clamp circuit. $19^{\text {th }}$ International Scientific Conference on Electric Power Engineering (EPE). Barcelona, 2009. Pp. 1-8.

8. S. Tomioka, S. Abe, M Shoyama, T. Ninomiya, E. Firmansyah, Zero-current-switched quasi-resonant boost converter in power factor correction application. 24 ${ }^{\text {th }}$ Annual IEEE Applied Power Electronics Conference and Exposition (APEC). 2009. Pp. 1165-1169.

9. Voytenko V., Stepenko S. Simulation peculiarities of high-frequency zero-current switching quasi-resonant boost converter. Proc. IEEE 35 th IEEE International Conference on Electronics and Nanotechnology Ukraine, 21-24 April 2015. Pp. 486-491. DOI:

ELNANO2015. Kyiv,

https://doi.org/10.1109/ELNANO.2015.7146935

$\underline{\text { PDF }}$ 